\title{
Miningo
}

http://dx.doi.org/10.1590/0370-44672016700163

\author{
Gianluca Bella \\ Ph.D. Candidate \\ Politecnico di Torino - DISEG \\ Torino - Piemonte - Italy \\ gianluca.bella@polito.it
}

Fernando Soares Lameiras

Pesquisador Titular

Centro de Desenvolvimento da

Tecnologia Nuclear - CDTN/CNEN

Belo Horizonte - Minas Gerais - Brasil

fsl@cdtn.br

Terezinha de Jesus Espósito

Professora Associada

Universidade Federal de Minas Gerais - UFMG

Escola de Engenharia

Departamento de Transporte e Engenharia Geotécnica

Belo Horizonte - Minas Gerais - Brasil

esposito@etg.ufmg.br

Monica Barbero

Assistant Professor

Politecnico di Torino - DISEG

Torino - Piemonte - Italy

monica.barbero@polito.it

\section{Fabrizio Barpi}

Assistant Professor

Politecnico di Torino - DISEG

Torino - Piemonte - Italy

fabrizio.barpi@polito.it

\section{Introduction}

Tailing dams are complex geotechnical structures that should be designed taking into account long-term stability and long-term properties of materials (DME, 1999; Szymanski, 1999; ONTARIO, 2000; Silva et al., 2003; Xendis et al., 2004; Bjelkevik, 2005; Jantzer and Knutsson, 2010; ANCOLD, 2011; ICOLD 2013). Long-term physical, chemical and geotechnical properties of tailings need to be deeply understood in order to approach engineering problems related to

\section{Aging simulation of the tailings from Stava fluorite extraction by exposure to gamma rays}

\begin{abstract}
Tailings storage facilities are disposal systems for storing the waste products of the mining industry consisting of a slurry mixture made of soil, rock and water that remain after the mineral values have been removed from the patent ore. Tailings dams are supposed to last forever, so after their deposition, tailings can experience aging processes with physical and chemical changes depending on the interactions between local conditions and source mineralogy. The consequences of these aging processes are increased interlocking of particles and oxidation processes, sometimes making previously safely held contaminants available and mobile. Among the long-term aging processes, the natural ionizing radiation (from radioactive isotopes of the soils, cosmic rays, and also ultraviolet rays from the sun) can be considered, as proposed in the current research. Furthermore, in many countries, tailings are beginning to be re-used as backfill, landscaping material or feedstock for cement and concrete. So if any, the long-term physical and chemical modifications could affect the hydraulic and mechanical behaviour of tailings with relevant economic consequences. For these reasons, wet and dry silty samples of tailings spilled out after the failure of the Stava tailings dam (Trentino Alto Adige, Italy) were exposed to gamma rays, as an accelerated aging technique to simulate the natural ionizing radiation, and then characterized. The modifications on physical and chemical properties were observed and, despite certain chemical stability, some physical changes were observed, particularly in terms of size particle distribution, inner porosity of the particles and specific surface.
\end{abstract}

Keywords: aging, tailings, irradiation, gamma rays. this complex material, i.e. stability analyses of tailing embankments, use of tailings as backfill, landscaping material, aggregate in road construction, or feedstock for cement and concrete paving, especially in Brazil, USA, Canada, China, India and Australia (Esposito et al.,2014).

Some studies concerning simulation of long-term processes on natural soils and tailings wastes can be found in literature, sometimes with contrasting results. Troncoso et al. (1988) studied the cyclic resistance on aged copper tailing samples by performing cyclic triaxial tests. They estimated that cementation between particles can increase the cyclic liquefaction resistance of the impoundment more than $250 \%$ over 30 years. The results of cyclic triaxial tests on the 30,5 and 1-year old quartz tailings samples are shown in Fig. 1a in terms of cyclic stress ratio (defined as the ratio of amplitude of cyclic axial stress to twice the initial confining stress) required to produce $5 \%$ double amplitude axial strain. 
Larrahondo and Burns (2014) performed some triaxial tests aimed to simulate the increased interlocking of particles (cementation), in order to evaluate the shear strength
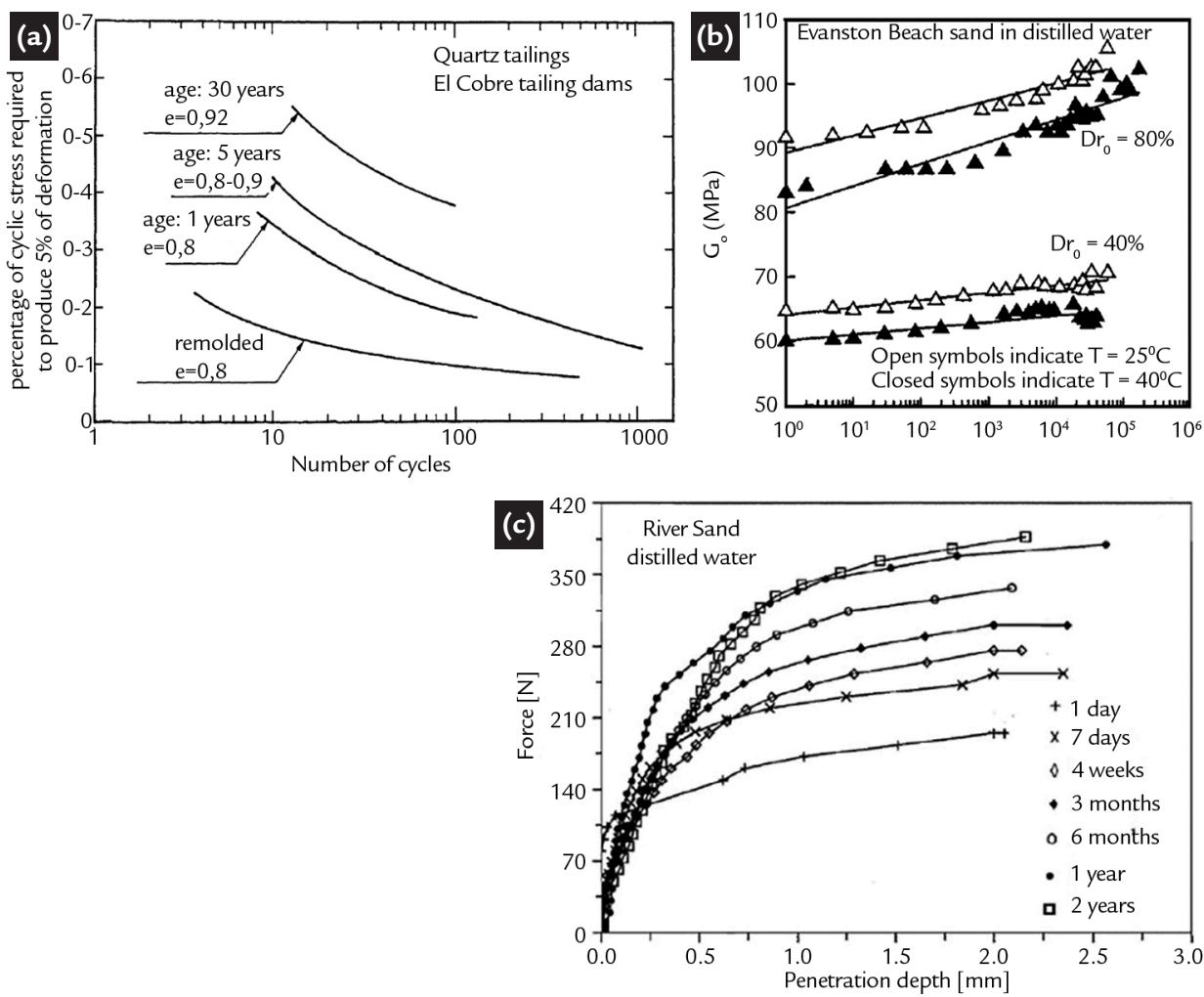

Craw et al. (1999) and Devasahayam (2007) performed chemical tests on tailings samples after drying, wetting and oxidation for 4 years, obtaining some chemical and mineralogical variations. Others laboratory studies on sandy soils show improvements with time due to the aging process (Mitchell and Solymar, 1984; Schmertmann, 1987; Mesri et al., 1990, Baxter and Mitchell, 2004) by showing increase of shear modulus G (Daramola, 1980, Schmertmann, 1991, Pender et al., 1992), and also at small strains, $G_{0}$ (Afifi and Woods, 1971; Anderson and Stokoe, 1978; Baxter and Mitchell, 2004 as shown in Fig. 1b), liquefaction resistance (Seed, 1979; Ishihara, 1985) and penetration resistance, as reported by Joshi et al. (1995, Fig. 1c). Despite an increasing number of examples of property improvements, there are field studies (Baxter, 1999; Jefferies et al. 1988; Charlie et al. 1992; Jefferies and Rogers, 1993) and laboratory tests (Human, 1992; Miller, 1994; Baxter; Mitchell, 2004) on sandy samples in which no significant aging effects, such as an increase of penetration resistance, were shown.

In the deposit, tailing materials are subjected to physical and chemical alterations due to weathering and other factors. Several minerals contain potassium in their composition, which is composed of $0.01 \%$ of ${ }^{40} \mathrm{~K}$, a natural occurring isotope that emits beta rays and gamma rays. On the surface of tailings deposits or in the tailings bricks faces used for constructions, the minerals are exposed to cosmic rays and ultraviolet rays. The energy of sandy tailing wastes, showing an increasing of the friction angle at the critical state.
Figure 1

(a) Increasing of liquefaction resistance from cyclic triaxial tests (modified from Troncoso et al., 1988). (b) changes of shear modulus at small strains with time for Evanston Beach sand in distilled water at two relative densities and temperatures (Baxter and Mitchell, 2004). (c) Increasing penetration resistance with time for aged River Sand in wet conditions (modified from Joshi et al., 1995).

of these radiations are absorbed by the minerals by displacing electrons from their original positions in the crystal structure of minerals. In the long-term; these radiations may trigger alterations of the materials due to their ionizing character. Aimed to study the effects of ionizing radiation on tailings and its influence on physical and chemical properties, induced aging tests were performed by means of exposure to gamma rays, and are reported in this paper. Silty tailings samples from Stava (Italy) fluorite extraction were chosen. Dry and wet samples were exposed to gamma rays from a ${ }^{60} \mathrm{Co}$ source up to a dose of $1000 \mathrm{kGy}$ in order to simulate the aging process in two extreme cases: dry conditions if tailings are used for bricks, wet conditions for tailings deposited within the storage facility.

\section{Material properties and testing techniques}

Tailings used in this research were collected in 2005 from the lower portion of the Stava upper dam, after its failure in 1985. They were deposited within two tailings storage facilities raised with the upstream method, built one above the other on a natural slope near village of Stava (Italy) and aimed to store the slurry tailings coming from the separa- tion floatation process of the Prestavel fluorite mine (Sarsby, 2013). The lower embankment failed due to overtopping caused by the failure of the upper one, triggering a flowslide consisting of more than $200000 \mathrm{~m}^{3}$. The mixture of water debris and sediments travelled down the Stava valley to speeds of $90 \mathrm{~km} / \mathrm{h}$ obliterating everything in its path for a stretch of $4.2 \mathrm{~km}$, until it reached the municipality of Tesero and then it flowed into the Avisio river, causing 269 deaths and damages valued at 133 million euros (Lucchi, 2011). Factors such as high phreatic level, poor drainage, and the unconsolidated state of the tailings have caused the static liquefaction that led to the collapse of the Stava tailings dam. 


\subsection{Material characterization}

After collection in 2005 and until running the tests, Stava tailing were kept air dried at a constant temperature equal to $22^{\circ} \mathrm{C}$. Only the silty fraction of the Stava tailings passing through sieve ASTM n ${ }^{\circ} 200$ was tested. This

Table 1

Geotechnical index properties of Stava tailings (Carrera, 2008).

Table 2

Characterizations

performed on the tailing samples.

From Sample 1, a second sample, $500 \mathrm{~g}$ weight, labeled Sample 2, was obtained and then treated by means gamma irradiation in the form of loose, choice was done in order to simplify the experimental program even if it is well recognized that, because of the adopted deposition technique, tailing basins are characterized by a great heterogeneity of materials in terms of grain size dis- tribution. Geotechnical characteristics of the Stava tailings are summarized in Tab. 1. A sample of $1 \mathrm{~kg}$ of silt, labelled Sample 1 , was oven dried at $120^{\circ} \mathrm{C}$ for 24 hours and then characterized as shown in Tab. 2.

\begin{tabular}{c|c|c|c|c|c} 
Property & $\begin{array}{c}\text { Specific weight, } \\
\mathrm{G}_{\mathrm{S}}\left(\mathrm{g} / \mathrm{cm}^{3}\right)\end{array}$ & $\begin{array}{c}\text { Permeability, } \\
\mathrm{k}(\mathrm{m} / \mathrm{s})\end{array}$ & $\begin{array}{c}\text { Liquid limit, } \\
\mathrm{W}_{\mathrm{L}}(\%)\end{array}$ & $\begin{array}{c}\text { Plastic limit, } \\
\mathrm{w}_{\mathrm{p}}(\%)\end{array}$ & $\begin{array}{c}\text { Plasticity } \\
\text { index, } \mathrm{PI}\end{array}$ \\
\hline Finer fraction & 2.828 & $2.10^{-7} \div 4.10^{-9}$ & 27.4 & 18.0 & 9.4 \\
\hline Coarser fraction & 2.721 & $1.10^{-5} \div 9.10^{-6}$ & 27.4 & 18.0 & 9.4 \\
\hline
\end{tabular}

\begin{tabular}{|c|c|c|}
\hline Property & Technique & Equipment \\
\hline Grain size distribution & Laser diffraction & Cilas, model 1190 \\
\hline Electronic microscopy & SEM & Carl Zeiss, model VP \\
\hline Energy dispersive X-rays spectroscopy & EDS & Bruker, model XFlash 4.0 \\
\hline Particle morphology & Image analysis & Software Quantikov* \\
\hline Particle density & Helium pycnometry & $\begin{array}{l}\text { Quantachrome, } \\
\text { model Ultrapycnometer }\end{array}$ \\
\hline Specific surface and pore diameter & $\mathrm{N}_{2}$ adsorption & $\begin{array}{l}\text { Quantachrome, } \\
\text { model NOVA } 2000\end{array}$ \\
\hline \multirow[t]{2}{*}{ Chemical analysis } & Infrared spectroscopy & ABB Bomem, model MB102 \\
\hline & X-rays fluorescence & \\
\hline Mineral composition & X-rays diffractometry & Rigaku, model $\mathrm{D} \backslash \mathrm{MAX} \backslash \cup L I M A^{* *}$ \\
\hline
\end{tabular}

* Pinto (1996). ${ }^{* *}$ XRD spectra collected with Cu-Ka radiation and data collected with $2 \theta$ in the range of $20^{\circ}-80^{\circ}$.

dry material. A third sample, $500 \mathrm{~g}$ weight, named Sample 3, was also obtained from Sample 1 and irradiated in wet conditions by means of adding a quantity of deionized water corresponding to the liquid limit in order to obtain a slurry.

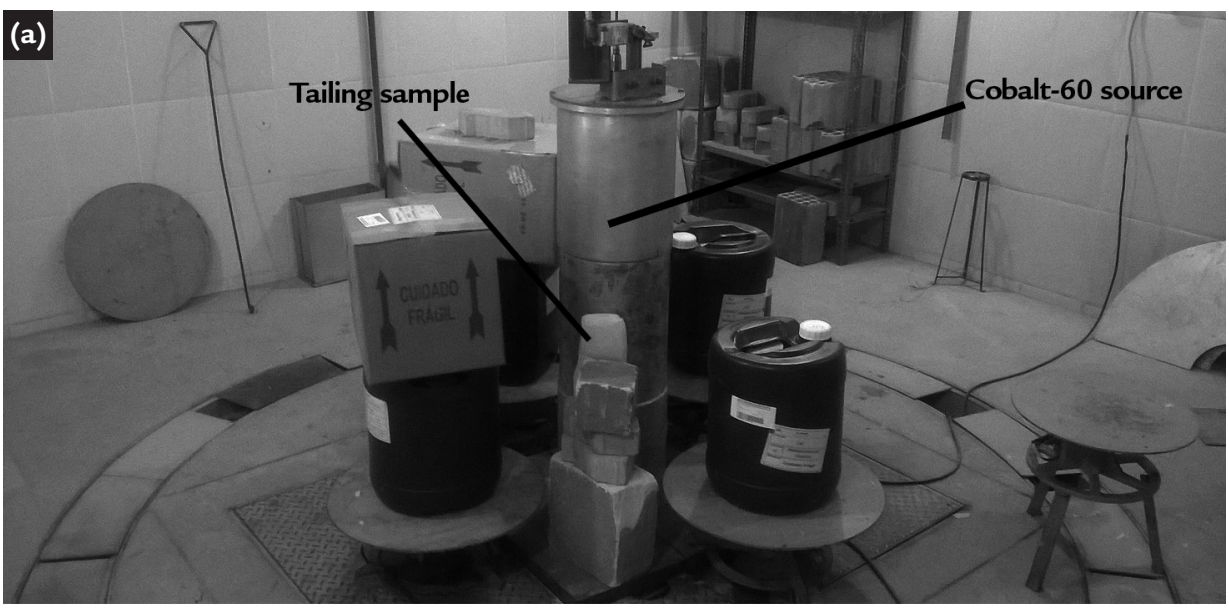

(b)

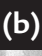

Figure 2

(a) Gamma irradiator, location of the tailing sample; (b) Dry sample before and after the treatment by gamma irradiation.
Before treatment dry sample

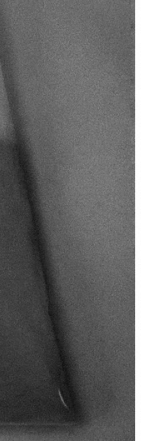

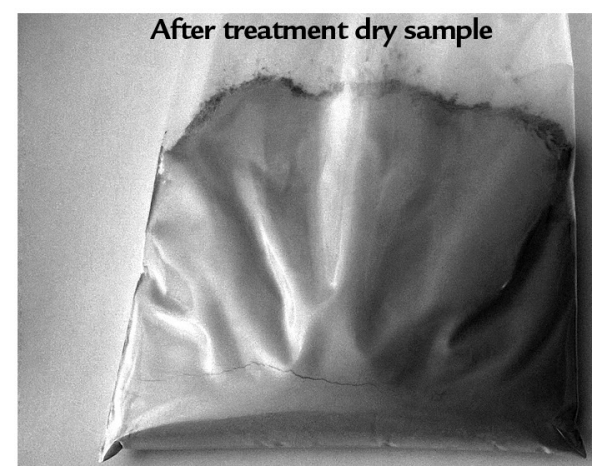




\begin{tabular}{c|c} 
Irradiation time & 7 days \\
\hline Exposure dose & $1000 \mathrm{kGy}$ \\
\hline Distance to the gamma source & $0 \mathrm{~cm}$ \\
\hline Gamma source & ${ }^{60} \mathrm{Co}$ \\
\hline Photon energy & $1.17 \div 1.33 \mathrm{MeV}$ \\
\hline Frequency of gamma photon & $2.83 \times 10^{20} \div 3.22 \times 10^{20} \mathrm{~Hz}$ \\
\hline Temperature & Irradiation chamber temperature $\left(\right.$ about $\left.60^{\circ} \mathrm{C}\right)$ \\
\hline
\end{tabular}

Before the treatment, Sample 2 and Sample 3 were both sealed within plastic containers and then covered with aluminium paper and masking paper. The irradiations were performed at the laboratory of Centro de Desenvolvimento de Tecnologia Nuclear (Belo Horizonte, Brazil), in a panoramic multipurpose gamma irradiator,

\section{Results}

Mineral constituents were quantified carrying out X-rays diffractometry by using incident $\mathrm{X}$-rays through a not irradiated sample and irradiated samples, in dry and wet conditions. Diffractograms present practically the same peaks with the same intensities, meaning the three samples have the same composition, with fluorite $(50 \%)$ and quartz (35\%) as the main constituents, and calcite $(9 \%)$, muscovite $(3 \%)$, rutile $(0,3 \%)$ and dolomite $(0,5 \%)$ as the minor constituents. Little variations of mineral constituents before and after the treatment suggest no modifications occurred after irradiation.

The chemical composition was then investigated by means of X-rays fluorescence on a not irradiated sample and irradiated samples, again in dry and wet conditions. The X-ray fluorescence is a technique for quantitative identification of chemical elements by using incident X-rays through a solid sample (Beckhoff et al., 2006). The elementary composition is practically the same for all samples, giving high percentages of calcium $(34 \%)$, aluminium $(27 \%)$, fluorine $(26 \%)$ with traces of potassium category II, from MDS Nordion, model IR-214 BG-127, equipped with a ${ }^{60} \mathrm{Co}$ gamma source, dry storage, with maximum activity of $2200 \mathrm{TBq}$ or $60000 \mathrm{Ci}$. The samples were attached on the wall of the cylindrical gamma source as shown in Fig. 2. Table 3 summarizes the irradiation conditions. After the irradiation, Samples
$(3 \%)$, iron $(1.3 \%)$, zinc $(0.5)$, magnesium (0.4) and other elements, i.e. sodium and manganese.

The same results were observed from analyses performed by scanning electron microscope (SEM), by using the Energy Dispersive Spectroscopy technique (EDS), which showed the same spectra for all samples.

Figure $3 a, 3 b$ and $3 c$ show the Fourier Transform Infrared spectroscopy (FTIR) spectra of the three samples. This technique is a powerful tool for qualitative and quantitative identification of either organic or inorganic chemicals, impurities and percent crystallinity by using infrared radiation through solid, liquid or gaseous samples. Before the spectra acquisition, the samples were oven dried at $120^{\circ} \mathrm{C}$ for 24 hours, dispersed in potassium bromide $(\mathrm{KBr})$ and pressed in a form of thin disks. Potassium bromide was used in order to disperse the tailings powder to decrease the absorbance to infrared radiation. The mass of tailings and $\mathrm{KBr}$, as well as the compaction pressure, was the same in all disks, so that they had the same dimensions. By comparing the spectra
Table 3

Gamma irradiation conditions of the tailing samples 1, 2 and 3 .

2 and 3 were characterized according to Table 2. Use of gamma rays permits acceleration of the aging process. In one week, the high frequency gamma radiation used in this research (intensity $3,39 \cdot 10^{-2} \mathrm{~W} / \mathrm{cm}^{2}$ ) simulates about seventy years of continuous exposure of tailings samples to ultraviolet rays (intensity $250 \cdot 10^{-6} \mathrm{~W} / \mathrm{cm}^{2}$ ). of Samples 2 and 3 with Sample 1, it is possible to see small differences. Sample 2 shows a small band at $1262 \mathrm{~cm}^{-1}$, which was attributed to the formation of hydrated calcium oxalate, weddellite (Frost et al., 2003), probably due to the reaction of calcite and residual water. Samples 2 and 3 also show bands at $2923 \mathrm{~cm}^{-1}$ and $2966 \mathrm{~cm}^{-1}$, related to C-H or $\mathrm{C}-\mathrm{H}_{3}$ bonds and at $662 \mathrm{~cm}^{-1}$, related to $\mathrm{Si}-\mathrm{Al}-\mathrm{O}$ bonds.

Figures $3 \mathrm{~d}$ and $3 \mathrm{e}$ show the particle size distributions (Stojanovic and Markovic, 2012) of Samples 2 and 3 compared with Sample 1. Considering Sample 1 (before irradiation) and Sample 2 (after dry irradiation), there is a $3.2 \%$ of volume decrease of particles with sizes between $19 \mu \mathrm{m}$ and $100 \mu \mathrm{m}$. The same amount is related to a volume increase of particles with sizes between $0.5 \mu \mathrm{m}$ and $10 \mu \mathrm{m}$. In the case of Sample 3 (after wet irradiation), there is a $3.0 \%$ volume decrease between 19 and $100 \mu \mathrm{m}$ and the same amount of volume increase between $0.5 \mu \mathrm{m}$ and $10 \mu \mathrm{m}$. By comparing Samples 2 and 3, the differences in particle size distributions are very small (0.3 to $0.4 \%$ in volume). 


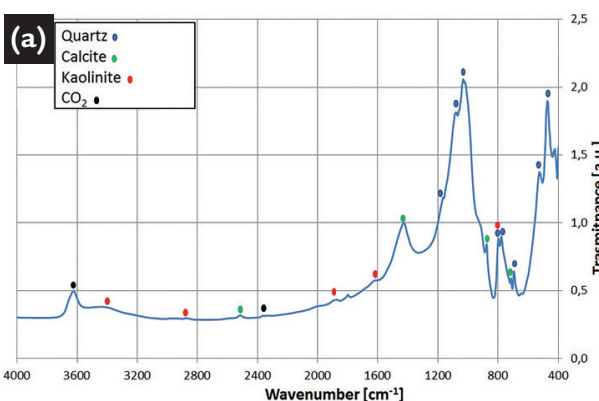

(b)

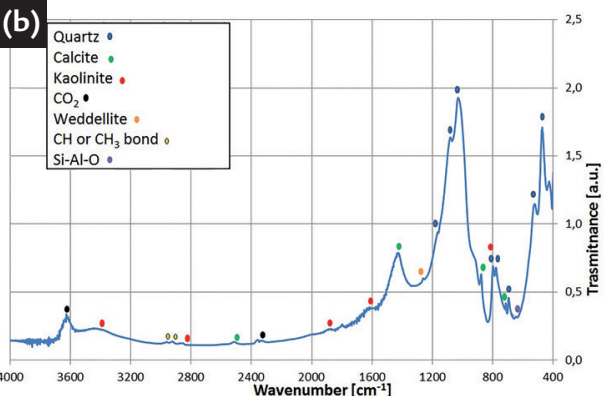

Figure 3

Fourier transform infrared spectroscopy spectra for not irradiated sample (a), dry irradiated sample (b) and wet irradiated sample (c). Comparison

between grain size distribution of not irradiated-dry irradiated sample (d), and not irradiated-wet irradiated sample (e).

Images obtained by scanning electron microscopy are shown in Fig. 4 with $450 \mathrm{X}$ magnification. Particles of

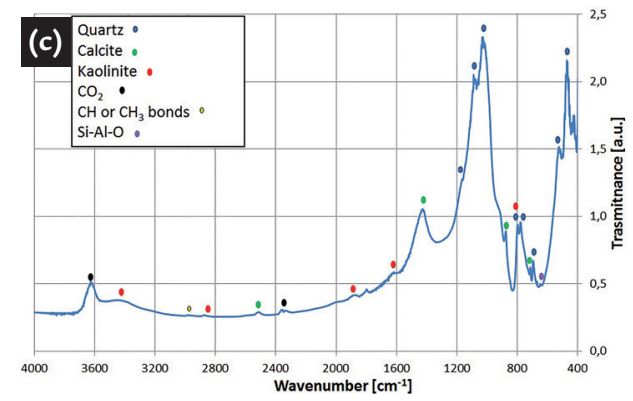

Sample 1 appear well defined, while, after irradiation, particles appear smaller and show a slight trend to form clusters. (d)

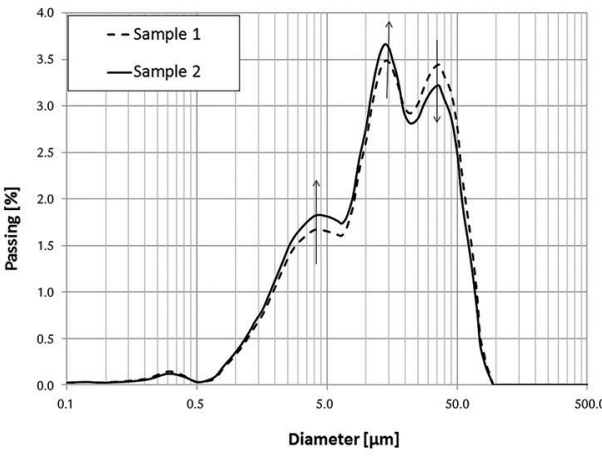

(e)

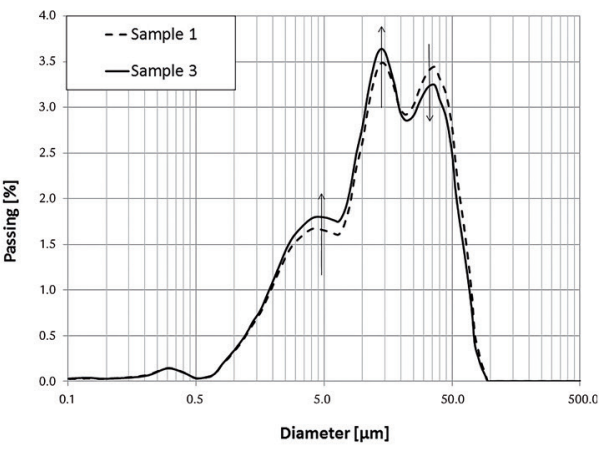

Table 4 shows the results of image analysis. All samples show the same roundness (Koivuranta et al., 2013) of about 0.7.
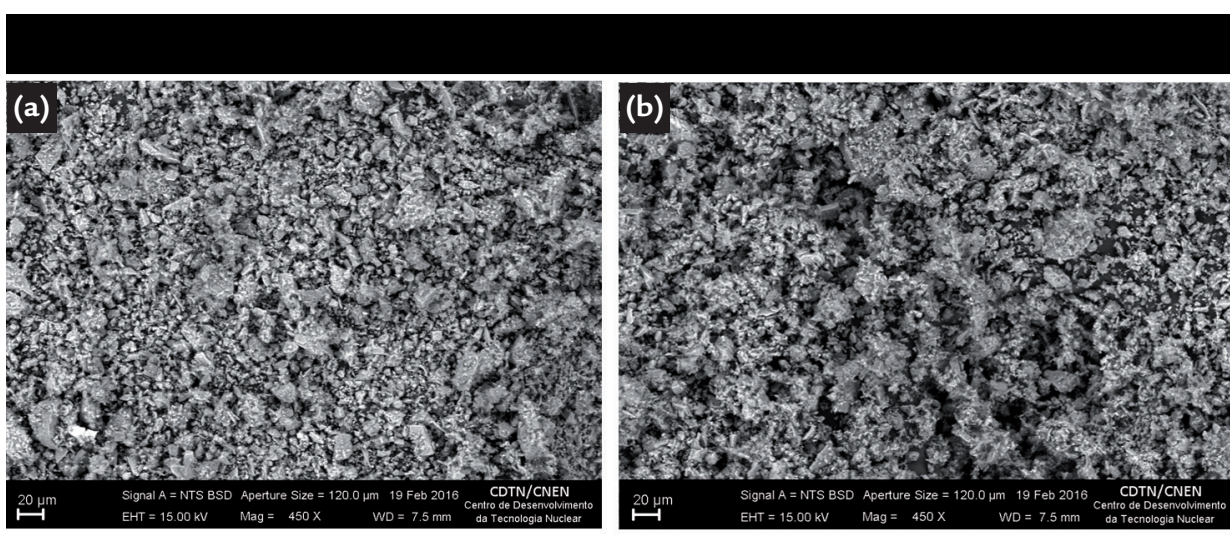

Figure 4

(a) SEM images for not irradiated sample;

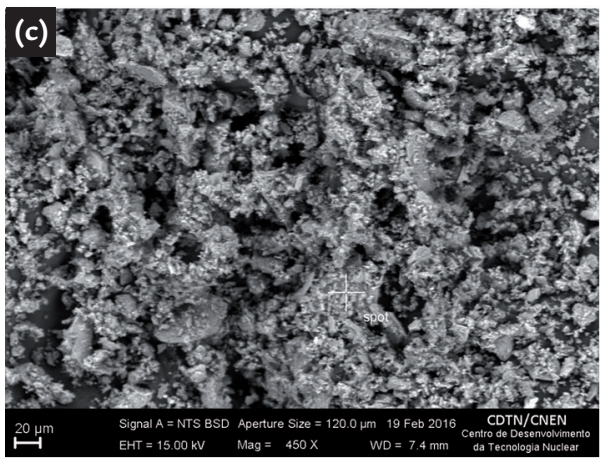

(b) SEM images for dry irradiated sample,

(c) SEM images for wet irradiated sample. 


\begin{tabular}{c|c|c|c|c} 
& Technique & Sample 1 & Sample 2 & Sample 3 \\
\hline Area $\left(\mu \mathrm{m}^{2}\right)$ & SEM & 245.77 & 198.74 & 199.42 \\
\hline Diameter $(\mu \mathrm{m})$ & SEM & 15.64 & 14.86 & 14.35 \\
\hline Roundness & SEM & 0.72 & 0.71 & 0.68 \\
\hline Specific surface $\left(\mathrm{m}^{2} / \mathrm{g}\right)$ & $\mathrm{N}_{2}$ adsorption & 5.35 & 5.65 & 5.72 \\
\hline Particle porosity $(\%)$ & $\mathrm{N}_{2}$ adsorption & 3.83 & 4.32 & 4.43 \\
\hline True density $\left(\mathrm{g} / \mathrm{cm}^{3}\right)$ & Helium pycnometry & 2.897 & 2.906 & 2.943 \\
\hline Average pore diameter $(\AA)$ & $\mathrm{N}_{2}$ adsorption & 102.741 & 109.872 & 106.362 \\
\hline
\end{tabular}

Irradiated samples show an average diameter $(14.6 \mu \mathrm{m})$ smaller than the not irradiated one $(15.6 \mu \mathrm{m})$. In terms of surface, tailings particles of the not irradiated sample are bigger than the irradiated ones.

These results are in good agreement with laser particle analysis. By analysing

\section{Discussion}

The tailing samples tested in this study are composed of fluorite, quartz, calcite, kaolinite and small amounts of rutile and dolomite. Small changes were observed in the FTIR spectra of irradiated samples, which can probably be attributed to reactions in consequence of the ionization character of gamma rays. A small fraction of larger particles (about $3 \%$ in volume) were disintegrated into

\section{Conclusions}

Indirect aging tests were performed on silty samples of Stava tailings dams, by means of gamma radiations bombardment carried out at Centro de Desenvolvimento de Tecnologia Nuclear in Belo Horizonte (Brazil). Tailings were treated and characterized both in dry and wet conditions in order to analyze the influence of UV radiations on the chemical and physical properties of tailings on the surface of tailings deposits or in the tailings brick faces used for buildings. Physical modifications have been studied by means of different characterization tests before and after the ionizing treatment. Changes in terms of particle size distribution were observed after irradiation in dry and wet conditions. In both cases an increase of some silty fractions was

\section{Acknowledgements}

The authors wish to thank all CDTN and UFMG staff, in particular Prof. Ana Maria Matildes dos Santos, Prof. Monica M. A. M. Schvartzman, area, average diameter and roundness of Sample 2 and Sample 3, it is possible to observe there are no meaningful differences, if the ageing process is carried out on dry or wet tailings samples.

The results of specific surface, particle density and pore diameter, obtained small particles. The consequences were the decrease of the mean particle size and increase of the specific surface of the irradiated samples. The inner porosity of the irradiated particles also increased, maybe due to an increase of the inner pore sizes. Dry and wet irradiation produced practically the same results.

The obtained results allow to assert that the tailings analysed in the current observed. Processing of the digital SEM pictures showed a reduction of area and average diameter of grains for Sample 2 and Sample 3. Adsorption tests showed an increase of the specific surface area after the treatment. Contextually, an increase in the particle porosity of grains was obtained. From the chemical point of view, the tailings samples exhibit a certain stability. X-ray diffraction, fluorescence and EDS analysis showed little changes of concentration of the constituent elements before and after the treatments. Finally, for Sample 2 and Sample 3, infrared spectroscopy showed peaks due to the presence of new chemical bonds.

It is worth noting that the wet irradiation was carried out in pure water, while the real environment is more
Prof. João Batista Santos Barbosa, Prof. Lúcio Carlos Martins Pinto, Dr. Sérgio Carneiro dos Reis, Prof. Tércio Assunção Pedrosa and Prof. Vanessa de
Table 4

Results of image analysis of

SEM images, helium pycnometry

and $\mathrm{N}_{2}$ adsorption of tailing samples.

by helium pycnometry and $\mathrm{N}_{2}$ adsorption techniques, are shown in Table 4. It is possible to observe an increase of the specific surface, particle porosity and average pore diameter (inside of the particles) of the irradiated samples. The true density is practically the same for all samples. research have shown a certain physical and chemical stability if exposed to solar radiation for about 70 years. Depending on their ionizing energy, cosmic rays and ultraviolet rays from the sun have a penetration depth equal to about $1 \mathrm{~cm}$. Based on results of the current physical and chemical characterization, the effects on mechanical and hydraulic of tailings are not relevant. complex. In the site, tailings are mixed with water which contains dissolved salts, heavy metals, contaminants and residual chemicals from the mineralogical processes. This choice was adopted to simplify the experimental program. Hence, in order to improve the affinity with the real environment, further wet irradiations tests can be carried out by using processing water. Additionally, other tests can also be performed by increasing the photon energy emitted by gamma rays, in order to simulate a greater aging period both on dry and wet samples, as well as the mixtures made of sandy and silty tailings in different percentages have to be tested in order to take into account the heterogeneity of in situ tailings.
Freitas Cunha Lins for their help during the realization of all laboratory tests presented in this work. 
AFIFI, S.S., WOODS, R.D. Long-term pressure effects on shear modulus of soils. J. Soil Mech. Found. Div., v. 97, p. 1445-1460, 1971.

ANDERSON, D.G., STOKOE, K.H. Shear modulus, a time-dependent soil property. Dynamic Geotechnical Testing, ASTM STP, v. 654, p. 66-90, 1978.

AUSTRALIAN COMMITTEE ON LARGE DAMS (ANCOLD). Guidelines on tailings dams - planning, design, construction, operation and closure. Austrália, 2011. p. 60.

BAXTER, C.D.P. An experimental study on the aging of sands. Blacksburg, Virginia: Virginia Polytechnic Institute and State University, 1999. (PhD Thesis).

BAXTER, C.D.P, MITCHELL, J. Experimental study on the aging of sands. J. of Geotechnical and Geoenvironmental Engineering. v. 130, p. 1051-1062, 2004.

BECKHOFF, B., KANNGIEBER, B., LANGHOFF, N., WEDELL, R., WOLLFF, H. Handbook of Practical X-Ray Fluorescence Analysis. Springer, 2006.

BJELKEVIK, A. Stability of tailings dams focus on water cover closure. Sweden: Luleå University of Technology, 2005. (Licentiate Thesis).

BJELKEVIK, A. Water cover closure design for tailings dams - state of the art report, Sweden: Luleå University of Technology, Department of Civil and Environmental Engineering, Division of Geotechnology, 2005a. p. 82.

CARRERA, A. Mechanical behaviour of Stava tailings. Politecnico di Torino, 2008. (PhD Thesis).

CHARLIE, W.A., RWEBYOGO, M.F.J., DOEHRING, D.O. Time-dependent cone penetration resistance due to blasting. J. Geotech. Eng., v. 118, p. 1200-1215, 1992.

CRAW, D., CHAPPEL, D., NELSON, M., WALROND, M. Consolidation and incipient oxidation of alkaline arsenopyrite-bearing mine tailings, Macraes Mine, New Zealand. Applied Geochemistry, v. 14, p. 485-498, 1999.

DARAMOLA, O. Effect of consolidation age on stiffness of sand. Geotechnique, v. 30, p. 213-216 1980.

Department of Minerals and Energy (DME). Guidelines on the safe design and operating standards for tailings storage. Western Australia, Government of Western Australia: Department of Minerals and Energy, 1999. p. 26.

DEVASAHAYAM, S. Application of particle size distribution analysis in evaluating the weathering in coal mine rejects and tailings. Fuel Processing Tech., v. 88, p. 295-301, 2007.

ESPOSITO, T., MANTILLA, J.N.R., CARRASCO, E.V.M., MOREIRA, L.E. Utilização de rejeito de minério para a fabricação de tijolos de rejeito-cimento - TRC. In: CONGRESSO BRASILEIRO DE MECÂNICA DOS SOLOS E ENGENHARIA GEOTÉCNICA, 17. Procedings... Goiânia (Brazil), 2014.

FROST, R.L., JING, Y., DING, Z. Raman and FTIR spectroscopy of natural oxalates: implications for the evidence of life on Mars. Chinese Science Bulletin, v. 48, p. 1844-1852, 2003.

HUMAN, C.A. Time dependent property changes of freshly deposited or densified Sands. Berkeley: University of California at Berkeley, 1992. (PhD Thesis).

INTERNATIONAL COMMISSION ON LARGE DAMS (ICOLD). Bulletin 153 -Sustainable Design and Post-Closure Performance of Tailings Dams, 2013. 86 p.

ISHIHARA, K. Stability of natural deposits during earthquakes. In: INT. CONF. ON SOIL MECHANICS AND FOUNDATION ENGINEERING, 11. Proceedings... San Francisco, 1985. p. 321-376.

JANTZER, I. \& KNUTSSON S. Critical gradients for tailings dam design. In: INTERNATIONAL SEMINAR ON THE REDUCTION OF RISK IN THE MANAGEMENT OF TAILINGS AND MINE WASTE, 1. Perth, Austrália, 2010. p. 23-32. (Mine waste 2010).

JEFFERIES, M.G., ROGERS, B.T., STEWART, H.R., SHINDE, S., WILLIAMS-FITZPATRICK, D.J., WILLIAMS-FITZPATRICK S. Island construction in the Canadian Beaufort Se. Hydraulic Fill Structures, v. 21, p. 816-883, 1988.

JEFFERIES, M.G., ROGERS, B.T. Discussion of timedependent cone penetration resistance due to blasting, by W. A. Charlie, M. F. J. Rwebyogo and D. O. Doehring. J. Geotech. Eng., v. 119, p. 2008-2012, 1993.

JOSHI, R.C., ACHARI, G., KANIRAJ, S.R., WIJIWEERA, H. Effect of aging on the penetration resistance of sands, Canadian Geotechnical Journal, 
v. 32, p. 767-782, 1995.

KOIVURANTA, E., KESKITALO, J., HAAPALA, A., STOOR, T., SAREN, M., NIINIMAKI J. Optical monitoring of activated sludge flocs in bulking and non-bulking Conditions. Environ. Technol., v. 34, p. 679-686, 2013.

LARRAHONDO, J.M., BURNS, S.E. Laboratory-prepared iron oxide coatings on sands: surface characterization and strength parameters. J. of Geotechnical and Geoenvironmental Engineering, v. 140, p. 1-9, , 2014.

LUCCHI, G. L'attività mineraria in Val di Stava, In: Stava-Tesero la ricostruzione e la memoria, 1985-2010. Litotipografia Alcione, 2011. p. 23-50.

MESRI, G., FENG, T.W.E., BENAK, J.M. Postdensification penetration resistance of clean sands. J. of Geotechnical Engineering - ASCE, v. 116, p. 1095-1115, 1990.

MILLER, H.J. Development of instrumentation to study the effects of aging on the small strain behavior of sands. Durham: Univ. of New Hampshire, , N.H., 1994. (PhD Thesis).

MITCHELL, J., SOLYMAR, Z. Time-Dependent strength gain in freshly deposited or densified sand. Journal of Geotechnical Engineering - ASCE, v. 110, p. 1559-1576, 1984.

ONTARIO REGULATION 210/00, Mining Act, Ministry of Natural Resources, Ontario, Canadá, 2000. p. 22.

PENDER, M.J., PEPLOE, R.J., DUSKE, G.C. Simple shear compaction of basecourse aggregates. Geotechnical Risk- Identification, Evaluation, and Solutions, Proc., 6th Australia-New Zealand Conf. on Geomechanics, Christchurch, New Zealand, 1992. p. 370-374.

PINTO, L.C.M. Quantikov: um analisador microestrutural para o ambiente windows. (PhD Thesis). São Paulo: Instituto de Pesquisas Energéticas e Nucleares (IPEN), 1996.

SARSBY, R. Environmental geotechnics. ICE Publishing, 2013.

SCHMERTMANN, J.H. Discussion of time-dependent strength gain in freshly deposited or densified sand, by J. Mitchell and Z. V. Solymar. J. of Geotechnical Engineering - ASCE, v. 113, p. 173-175, 1987.

SCHMERTMANN, J.H. The mechanical aging of soils. J. of Geotechnical Engineering, American Society of Civil Engineers, v. 117, p. 1288-1330, 1991.

SEED, H.B. Soil liquefaction and cyclic mobility evaluation for level ground during earthquakes. J. Geotech. Eng. Div. Am. Soc. Civ. Eng., v. 105, p. 201-255, 1979.

SILVA, D.V.R, OLIVEIRA FILHO, W.L. Estudos experimentais do processo de ressecamento de um rejeito fino de mineração. Revista Escola de Minas, v. 56, p. 261-265, 2003.

STOJANOVIC, Z., MARKOVIC, S. Determination of particle size distribution by laser diffraction. Technics-New Materials, v. 21, p. 11-20, 2012.

SZYMANSKI, M.B. Tailings dams from the perspective of conventional dam engineering. In: CANADIAN DAM SAFETY CONFERENCE. Sudbury, Canadá, 1999.

TRONCOSO, J.H., ISHIHARA, K., VERDUGO, R. Aging effects on cyclic shear strength of tailings materials. In: WORLD CONFERENCE ON EARTHQUAKE ENGINEERING, 9. Proceedings... Tokyo-Kyoto, Japan. 1988. p. 121-126.

XENDIS, A., MYLONA, E., PASPALIAIS, I., CSOVARI, M., NEMETH, G. Tailings management facilities - implementation and improvement of closure and restoration plans for disused tailings facilities. Report of the European RTD project TAILSAFE. Greece: National Technical University of Athens; Hungary: Mecsek-Öko Rt., Pécs, 2004. p. 54.

Received: 18 November 2016 - Accepted: 11 May 2017. 